\title{
HUBUNGAN ANTARA STRUKTUR ORGANISASI DENGAN EFEKTIFITAS ORGANISASI DI PESANTREN
}

\section{RELATIONSHIP BETWEEN ORGANIZATIONAL STRUCTURE WITH THE EFFECTIVENESS OF THE ORGANIZATION IN PESANTREN}

\author{
Djamaluddin Perawironegoro \\ Universitas Ahmad Dahlan, Yogyakarta, Indonesia \\ Email: djamaluddin@mpai.uad.ac.id
}

\begin{abstract}
Abstrak
Tujuan dari penelitian ini adalah untuk mengembangkan model struktur organisasi di pesantren yang memiliki keterkaitan dan pengaruh dengan efektivitas organisasi. Penelitian ini merupakan penelitian kuantitatif dengan analisis pemodelan persamaan struktural. Sumber data dari 273 pengelola dikumpulkan dari 98 unit profit dan non profit yang ada di Pesantren. Untuk menganalisis data peneliti menggunakan Partial Least Square (PLS-SEM) dengan Smart PLS 2.0 sebagai alat bantu. Hasil dari penelitian ini diperoleh hasil korelasi sebesar 0,553 yang berarti terdapat hubungan antara struktur organisasi dengan efektivitas organisasi pada level menengah. Hasil koefisien determinasi menunjukkan 0,305 (30,5\%) bahwa terdapat pengaruh yang signifikan dari struktur organisasi terhadap efektivitas organisasi di pesantren.
\end{abstract}

Kata Kunci: struktur organisasi, efektifitas organisasi, pesantren

\begin{abstract}
The purpose of this research is to develop the model of organizational structure in Pesantren that have the relationship and an impact with organizational effectiveness. This research is quantitative research with structural equation modeling analysis. Sources of data from 273 managers were collected from 98 various profit and non-profit unit in Pesantren. To analyze data the researcher used a Partial Least Square (PLS-SEM) with Smart PLS 2.0 as a tool. The result from this research is correlation result 0,553, it's mean that there is correlation between organizational structure and organizational effectiveness at middle level. The result from determinant coefficient showed 0,305 (30,5\%) that there is significant effect from organizational structure toward organizational effectiveness in Pesantren.
\end{abstract}

Keywords: organizational structure, organizational effectiveness, pesantren 
Djamaluddin Perawironegoro: Hubungan antara Struktur Organisasi dengan Efektifitas Organisasi di Pesantren

\section{A. Pendahuluan}

Robbins mengungkapkan bahwa keefektifan organisasi adalah tingkatan pencapaian organisasi atas tujuan jangka pendek (tujuan) dan jangka panjang (cara). Pemilihan itu mencerminkan konstituensi strategis, minat pengevaluasi, dan tingkat kehidupan organisasi. ${ }^{1}$ Sedangkan Steers mengemukakan bahwa batu uji yang sebenarnya untuk manajemen yang baik adalah kemampuan mengorganisasi dan memanfaatkan sumber-daya yang tersedia dalam tugas untuk mencapai dan memelihara suatu tingkat operasi yang efektif. ${ }^{2}$

Robbins, menyampaikan hal yang membuat organisasi efektif adalah struktur organisasi yang tepat. ${ }^{3}$ Di sini dimaksudkan bahwa struktur organisasi mengandung makna kompleksitas, formalisasi, dan sentralisasi.

Pesantren sebagai lembaga pendidikan Islam, memiliki masalah yang kompleks dalam menjaga keberlangsungan hidupnya. Pokok masalahnya sebagaimana diungkapkan oleh Madjid adalah terletak pada lemahnya visi dan tujuan yang dimiliki pesantren. Tidak adanya perumusan tujuan itu disebabkan adanya kecenderungan visi dan tujuan pesantren diserahkan pada proses improvisasi yang dipilih oleh kiai atau bersama-sama pembantunya secara intuitif yang disesuaikan dengan perkembangan pesantrennya. $^{4}$

Lebih lanjut Wahid, menyampaikan bahwa problem pesantren pada umumnya adalah masalah organisasi, cukup banyak pesantren yang menurun mutunya karena organisasinya tidak baik dan tidak mampu mengantisipasi tuntutan zaman. Ada juga yang mengalami gesekan internal sehingga mengganggu jalannya pesantren. ${ }^{5}$

Mastuhu menyampaikan perbedaan gaya kepemimpinan peantren dari jenis karismatik menuju ke rasional, dari otoriter kebapakan menuju diplomatik partisitpatif dan dari Laisser-Faire menuju ke birokratik. ${ }^{6}$ Perubahan pola kepemimpinan menjadi

\footnotetext{
${ }^{1}$ Stephen P. Robbins, Teori Organisasi: Struktur, Desain, dan Aplikasi, alih bahasa Jusuf Udaya (Jakarta: Penerbit Arcan, 1994), 85

${ }^{2}$ Richard M. Steers, Efektifitas Organisasi, alih bahasa Magdalena Jamin (Jakarta: Lembaga PPM dan Penerbit Erlangga, 1985), 1

${ }^{3}$ Robbins, Teori Organisasi..., 53

${ }^{4}$ Nurcholish Madjid, Bilik-Bilik Pesantren: Sebuah Potret Perjalanan (Jakarta: Paramadina, 1997), 6

${ }^{5}$ Shalahuddin Wahid, Transformasi Pesantren Tebuireng; Menjaga Tradisi di Tengah Tantangan (Malang; UIN-Maliki Press, 2011), 77-120

${ }^{6}$ Mastuhu, Dinamika Sistem Pendidikan Pesantren (Jakarta: INIS, 1994), 86
} 
efektif dengan diikuti perubahan pada struktur organisasi yang tepat. Seideal apapun seorang pemimpin, tidak memberikan perubahan yang signifikan terhadap pencapaian tujuan pesantren, jika tidak didukung dengan struktur organisasi yang tepat.

Berbagai petunjuk yang disampaikan oleh para ahli tersebut menunjukkan poinpoin penting terkait dengan pencapaian tujuan pesantren berdasarkan sumber daya yang dimilikinya. Beberapa pesantren belum memiliki visi yang jelas untuk lembaga pendidikannya. Kalaupun sudah memiliki, visi tersebut masih dibuat, disampaikan, dan diimprovisasi oleh kyai pendiri pesantren dan para pengurus yang bersamanya.

Dalam mencapai visi, pengelola pesantren memiliki kendala dengan problem utama yaitu organisasi internal. Problem organisasi secara internal dapat diketahui dari pola pengelolaan pesantren yang masih cenderung bersifat kekeluargaan. Demikian itu nampak, dengan pola kepemimpinan yang terpusat dalam pengambilan keputusan berdasarkan pada kyai pengelola pesantren. Tak jarang sumber daya manusia di pesantren ditentukan dengan pendekatan kekeluargaan.

Sampai pada tahap ini pesantren memiliki problem perumusan tujuan dan pengelolaan struktur organisasi yang dapat digunakan untuk mencapai tujuan tersebut. Untuk memberikan solusi pada hal tersebut, pendekatan manajemen dapat membantu menjawab masalah yang dihadapi oleh pesantren.

Studi yang dilakukan oleh Susnadati, Gammahendra et.al, Razia, dan Basol dan Dogerlioglu menjelaskan faktor-faktor yang memiliki pengaruh determinan atas efektifitas organisasi secara signifikan adalah; struktur organisasi, budaya organisasi, dan lingkungan organisasi. ${ }^{7}$ Amah et.al menyatakan tentang efektifitas organisasi yang dipengaruhi oleh ukuran organisasi. Ukuran organisasi dapat dikelola secara efektif untuk memberdayakan pekerja dan meningkatkan kinerja organisasi yang kompetitif. ${ }^{8}$

Hasil temuan kontradiktif disampaikan oleh Naserinajafabady et.al dalam penelitiannya menjelaskan bahwa tidak terdapat hubungan yang positif antara struktur

\footnotetext{
${ }^{7}$ Susnadati, "Faktor-faktor Determinan Keefektifan Organisasi SMA Negeri di Semarang Pada Era Desentralisasi Pendidikan," Disertasi, Program Studi Manajemen Pendidikan, Program Pascasarjana Universitas Negeri Semarang, 2007; Fianda Gammahendra, Djamhur Hamid, dan Muhammad Faisal Riza, "Pengaruh Struktur Organisasi terhadap Efektiftas Organisasi Studi Pada Persepsi Pegawai Tetap Kantor Perwakilan Bank Indonesia Kediri," Jurnal Administrasi Bisnis, Vol.7, No. 2, (2014): 1; Mbaraka Razia, "A Comparative Analysis of Organizational Structure and Effectiveness between Public and Private Universities; A Case of University of East Africa-Baraton and Moi University in Kenya," International Journal of Humanities and Social Science Invention, Vol. 4 (2015): 15-25; Esra Basol and Ozgur Dogerlioglu, "Structural Determinants of Organizational Effectiveness," Journal of Organizational Management Studies, (2014): 1-13.

${ }^{8}$ Edwinah Amah, Mildre Daminabo-Weje, dan Roberta Dosunmu, "Size and Organizational Effectiveness: Maintaining a Balance," Advances in Management \& Applied Economics, Vol. 3, No. 5 (2013): 115.
} 
Djamaluddin Perawironegoro: Hubungan antara Struktur Organisasi dengan Efektifitas Organisasi di Pesantren

organisasi dengan efektifitas organisasi. ${ }^{9}$ Vinitwatanakhun, dalam disertasinya menyatakan bahwa kepemimpinan, teknologi, strategi perencanaan, dan pengembangan sumber daya manusia memberikan penjelasan tentang efektifitas organisasi. Faktorfaktor lain seperti lingkungan, budaya, desain struktur, dan control kekuasaan tidak memberikan pengaruh terhadap efektifitas organisasi. ${ }^{10}$

Pesantren sebagai institusi pendidikan Islam tertua di Indonesia memiliki keunikan dibandingkan dengan madrasah atau sekolah formal pada umumnya. Keunikan tersebut terletak pada pola pendidikan yang mengharuskan seorang santri untuk tinggal di asrama selama 24 jam. Dari semenjak bangun tidur, para santri sudah "diatur" untuk mengikuti kegiatan bangun subuh kemudian shalat subuh berjama'ah. Hingga menjelang tidur lagi, diharuskan untuk menempati tempat tidur yang menjadi milik dan haknya.

Dalam rangka mengelola berbagai program pendidikan pesantren, kepala pesantren atau pengasuh pesantren menyusun suatu struktur organisasi yang memiliki fungsi dan tujuan untuk ketertiban dan keteraturan kegiatan yang direncanakan. Dengan demikian setiap program dapat diperhatikan keterlaksanaannya, dan dapat dievaluasi untuk hasil yang lebih baik.

Keberhasilan program dan kegiatan pesantren merupakan satu bagian kecil dari keberhasilan tujuan pesantren yang lebih besar. Sebagai contoh, tujuan pesantren adalah menumbuhkan rasa cinta kepada ilmu pengetahuan. Maka para pengelola pesantren, menyusun berbagai sarana dan prasarana untuk memfasilitasi para santri dengan kekuatan struktur organisasi yang dimiliki agar mencintai ilmu pengetahuan. Termasuk penciptaan lingkungan yang mendukung para santri agar mencintai ilmu.

Penelitian ini bertujuan untuk mencari hubungan antara struktur organisasi dengan efektifitas organisasi di pesantren. Dengan pengetahuan akan keterkaitan hubungan dan pengaruh dari struktur organisasi terhadap efektifitas organisasi, para pengelola pesantren dapat merumuskan struktur organisasi yang baik, dengan hal tersebut efektifitas atau ketercapaian tujuan pesantren dapat diraih dan dioptimalkan.

\footnotetext{
${ }^{9}$ Razieh Naserinajafabady, Hassan Rangriz, and Javad Mehrabi, "Effects of Organizational Culture, Structure, and Strategy on Organizational Effectiveness by Using Knowledge Management Case Study; Seven International Transportation Company," International Research Journal of Applied and Basic Science, Vol. 7, No. 6 (2013): 355-361

${ }^{10}$ Watana Vinitwatanakhun, "Factors Affecting Organizational Effectiveness of Nursing Institutes in Thailand," Ph.D Dissertation, in National Institute of Development Administration Bangkok Thailand 1998.
} 


\section{B. Metode Penelitian}

\section{Pendekatan dan Jenis Penelitian}

Penelitian ini adalah penelitian kuantitatif dengan jenis penelitian korelasi menggunakan alat analisis struktur persamaan model (Structural Equation Modelling) berbasis varian. Alat untuk menganalisis data menggunakan Smart PLS 2. Adapun penelitian ini dilaksanakan di Pondok Modern Darussalam Gontor Ponorogo Jawa Timur.

\section{Populasi dan Sampel Penelitian}

Populasi pada penelitian ini adalah seluruh pengurus pengelola unit-unit di pesantren yang dikelola oleh santri dan guru yang berjumlah 942 pengurus terdiri dari 478 guru, dan 464 santri. Dengan menggunakan teknik probably sampling, dibantu dengan rumus hitungan sample dari Isaac dan Michael dengan taraf kesalahan $5 \%$, ditentukan jumlah sample responden sebesar 273 sampel.

\section{Metode Pengumpulan Data}

Pengumpulan data dilakukan dengan menggunakan metode angket. Metode angket dipilih dengan asumsi bahwa untuk mendapatkan data akurat tentang keterlaksanaan struktur organisasi dan efektifitas organisasi pesantren lebih mudah dikumpulkan dengan instrumen angket. Instrumen angket dibuat dan disusun berdasarkan teori-teori dan konsep dalam manajemen konvensional yang dikombinasikan dengan konsep di pesantren sebagaimana disampaikan oleh ahli pesantren seperti Mastuhu dan Zarkasyi.

\section{Teknik Analisis Data}

Analisis data penelitian dilakukan setelah data dari instrumen penelitian dikumpulkan yang kemudian menghasilkan analisis deskriptif dan analisis inferensial. Analisis deskriptif dimaksudkan adalah menyampaikan data responden secara deskriptif tanpa memberikan tafsir dari data yang ada. Sedangkan analisis inferensial dimaksudkan adalah menyampaikan hasil data penelitian yang kemudian dikalkulasi menggunakan aplikasi Smart PLS 2.0 yang menghasilkan nilai untuk kemudian digunakan dalam uji hipotesis penelitian. 


\section{Hasil Penelitian dan Pembahasan}

\section{Analisis Deskriptif}

Jumlah sampel pada penelitian ini adalah 273 responden yang terdiri dari dua jenis pengurus yaitu santri dan guru. Tabel 1 menunjukkan distribusi deskripsi responden berdasarkan status pengurus:

Tabel 1. Deskripsi Responden Berdasarkan Status

\begin{tabular}{ccc}
\hline Status & Frekwensi (Orang) & Persentase \\
\hline Santri & 134 & 49.08 \\
\hline Guru & 139 & 50.92 \\
\hline Jumlah & 273 & 100 \\
\hline
\end{tabular}

Sumber: Olah data penelitian 2018

Data tersebut menunjukkan bahwa responden lebih banyan dari guru sebagai pengurus pengelola pesantren yaitu 139 responden atau 50,92 \%, sedangkan selebihnya yaitu 134 responden aatu 49, $08 \%$ adalah responden dari santri sebagai pengurus.

Berdasarkan unit yang dikelola oleh para pengurus tersebut dikelompokkan dalam tiga unit, yaitu: 1) unit yang dikelola oleh santri saja; 2) unit yang dikelola oleh guru; dan 3) unit guru yang dibantu oleh santri. Berikut tabel 2 menunjukkan deskripsi responden berdasarkan unit:

Tabel 2. Deskripsi Responden Berdasarkan Unit

\begin{tabular}{crr}
\hline Unit-Unit & Frekwensi (Orang) & Persentase \\
\hline Unit Santri & 93 & 34.06 \\
\hline Unit-Unit Guru & 139 & 50.92 \\
\hline Staff Unit & 41 & 15.02 \\
\hline Jumlah & 273 & 100.00 \\
\hline
\end{tabular}

Sumber: Olah data penelitian 2018

Berdasarkan data pada tabel 2 menunjukkan bahwa responden lebih banyak di unit-unit yang dikelola oleh guru yaitu 139 responden atau 50,92 \%, sedangkan berikutnya adalah unit santri sendiri sebanyak 93 responden atau 34,06 \%, dan staff unit atau unit guru yang dibantu oleh santri sebanyak 41 responden atau 15,02\%.

Dengan paparan data deskriptif responden berdasarkan status dan unit yang dikelola, demikian itu dapat menjadi pengetahuan bahwa responden pada penelitian ini adalah para pengurus yang aktif dalam organisasi atau unit-unit di pesantren. 


\section{Analisis Inferensial}

Analisis inferensial dilakukan dengan melakukan perhitungan berdasarkan data dari instrument angket penelitian. Data tersebut diberikan nilai untuk dihitung besaran nilai uji indikator dan uji hipotesis penelitian. Analisis model struktural berbasis varian dengan aplikasi Smart PLS 2.0 menjadi alat untuk menguji validitas indikator dan hipotesis penelitian. Hasil hitung menunjukkan sebagaimana pada gambar 1, sebagai berikut:

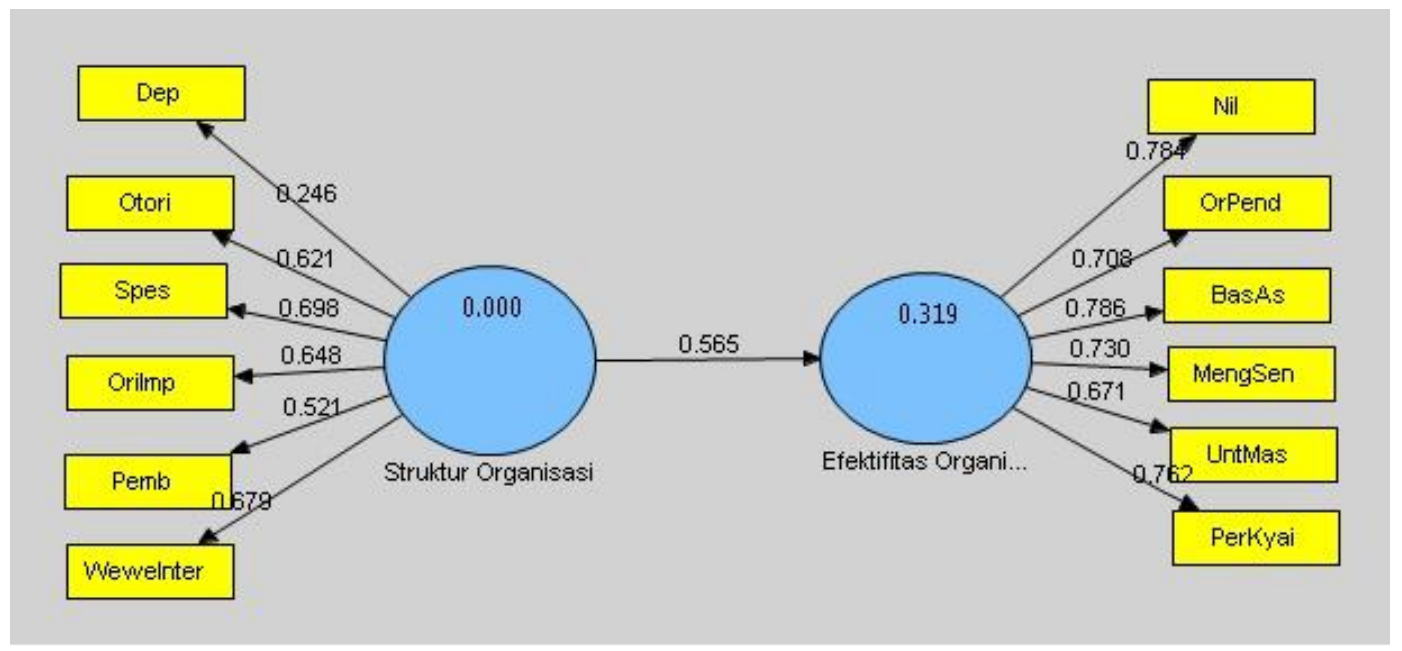

Gambar 1. Hasil Hitung Algoritma 1

Gambar tersebut menunjukkan nilai hasil hitung dari setiap indikator struktur organisasi yaitu: 1) departementalisasi 0,$246 ; 2$ ) otoritas 0,$621 ; 3$ ) spesialisasi 0,$698 ; 4$ ) orientasi impersonal 0,646 ; 5) pembagian kerja; 0,521; dan 6) wewenang interaktif 0,679. Indikator efektifitas organisasi pesantren menunjukkan: 1) nilai dan falsafah pesantren 0,$784 ; 2$ ) orientasi pendidikan 0,$709 ; 3$ ) pendidikan berbasis asrama 0,$786 ; 4$ ) masyarakat santri yang mengatur sendiri 0,$730 ; 5)$ pendidikan untuk masyarakat 0,762 ; dan 6) peran kyai 0,762. Semua indikator tersebut menunjukkan nilai yang lebih besar dari 0,5 kecuali indikator departementalisasi dari variabel struktur organisasi yang memiliki nilai 0,246. Demikian itu menunjukkan bahwa semua indikator adalah valid dalam mendeskripsikan variabel yang dihipotesakan, kecuali indikator departementalisasi. Untuk itu dilakukan hitungan ulang dengan tidak menyertakan indikator departementalisasi. Gambar 2 berikut adalah hasil perhitungan dengan menghilangkan indikator departementalisasi: 


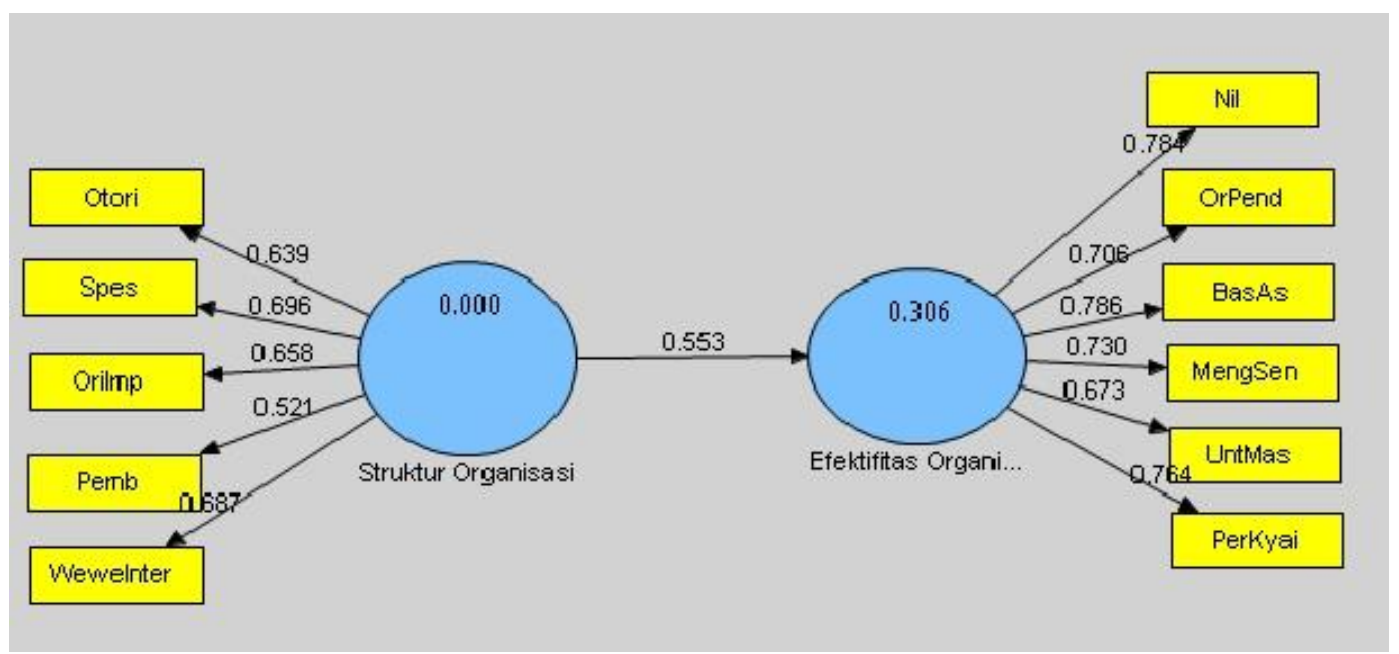

Gambar 2. Perhitungan algoritma 2

Gambar 2 menunjukkan semua indikator dari variabel struktur organisasi dan efektifitas organisasi memiliki nilai lebih besar dari 0,5. Demikian itu menunjukkan validitas semua indikator untuk memprediksi variabel-variabel yang dihipotesakan untuk memiliki hubungan. Berikut adalah perhitungan dengan menggunakan bootstrapping untuk menunjukkan nilai T-statistik dalam rangka menjawab hipotesis penelitian, sebagaimana pada gambar 3 berikut:

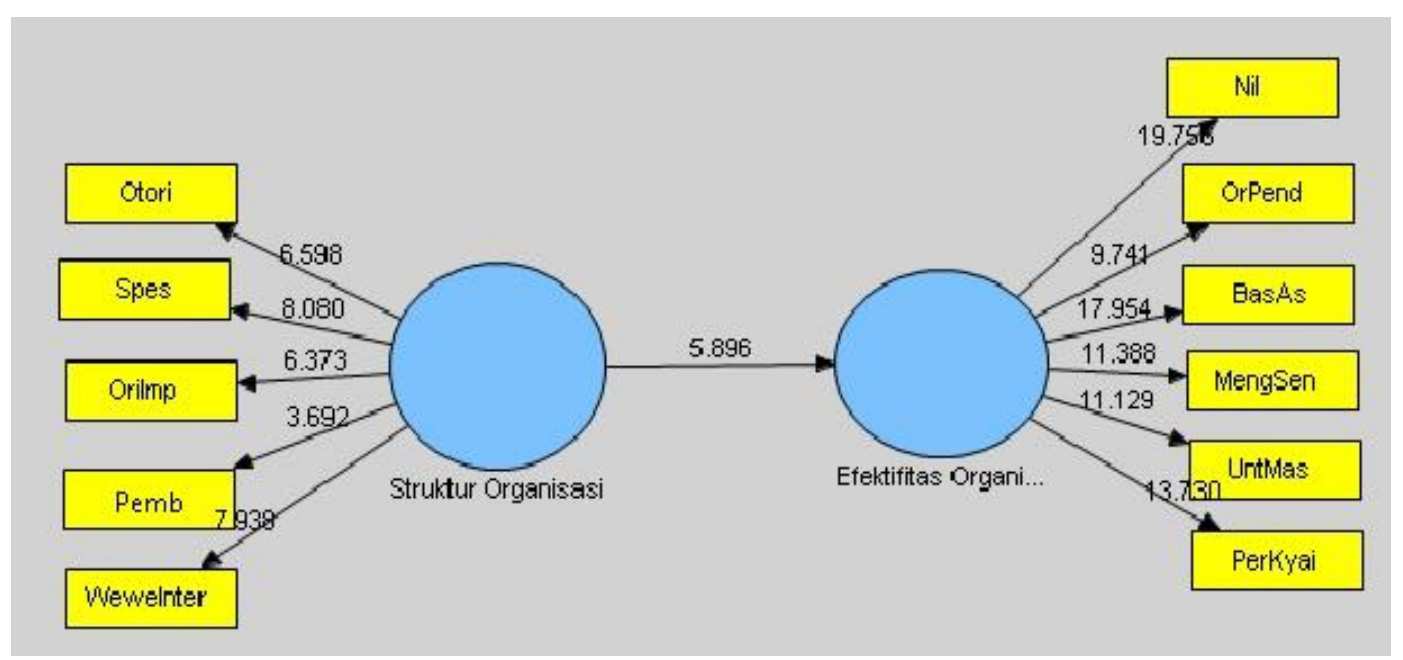

Gambar 3. Perhitungan bootstrapping

Gambar 3 menunjukkan nilai bootsrapping atau T-statistik sebesar 5.896 antara variabel struktur organisasi dengan efektifitas organisasi. Dengan melihat nilai T-tabel, yaitu 1,96 dapat difahami bahwa nilai T-statistik lebih besar daripada nilai T-tabel. Demikian itu dapat dimaknai dengan menolak $\mathrm{H}_{0}$, struktur organisasi berpengaruh terhadap efektifitas organisasi di pesantren. 
Tabel 3. Uji Struktural

\begin{tabular}{lc}
\hline Pengujian & Hasil Uji \\
\hline $\begin{array}{l}\text { Koefisien Determinasi } \\
\text { Struktur Organisasi }\end{array}$ & 0,305 \\
\hline $\begin{array}{l}\text { T-Statistik } \\
\text { Struktur Organisasi -> Efektifitas Pesantren }\end{array}$ & 5,896 \\
\hline $\begin{array}{l}\text { Koefisien Parameter } \\
\text { Struktur Organisasi -> Efektifitas Pesantren }\end{array}$ & 0,553 \\
\hline $\begin{array}{l}\text { Korelasi } \\
\text { Struktur Organisasi -> Efektifitas Pesantren }\end{array}$ & 0,553 \\
\hline
\end{tabular}

Sumber: Analisis data dengan Smart PLS 2.0

Berdasarkan hasil analisis data pada tabel 3 dapat diketahui bahwa efektifitas organisasi pesantren dipengaruhi oleh struktur organisasi sebesara $30,5 \%(0,305)$. Selebihnya yaitu $69,5 \%$, dipengaruhi oleh faktor lain yang tidak terdapat dalam model seperti budaya pesantren, manajemen sumber daya manusia, dan pengembangan organisasi.

Tabel 3 menunjukkan nilai T-statistik 5,896 yang lebih besar dari nilai T-tabel 1,96 dengan kemungkinan $5 \%$ dari derajat bebas. Demikian itu memiliki makna bahwa struktur organisasi memberikan pengaruh secara signifikan terhadap efektifitas organisasi pesantren.

Nilai koefisien parameter menunjukkan angka 0,553 artinya terdapat pengaruh positif dari manajemen sumber daya manusia terhadap efektifitas pesantren. Semakin tinggi struktur organisasi dijalankan, maka semakin tinggi efektifitas organiasi di pesantren.

Sedangkan nilai korelasi 0,553 pada tabel 5, menunjukkan terdapat hubungan antara struktur organisasi dengan efektifitas organisasi. Nilai korelasi 0,553 mengindikasikan hubungan yang cukup.

Kajian teoritis tentang pengaruh struktur organisasi terhadap efektifitas organisasi telah banyak dilakukan oleh para ahli manajemen. Robbins dan Judge, mengungkapkan bahwa untuk menuju pada tingkatan mengurangi ambiguitas dari para pegawai, dan klarifikasi tentang pekerjaan, pelaporan, kerjasama, dan koordinasi, struktur organisasi membentuk sikap, memfasilitasi, dan memotivasi mereka untuk kinerja yang tinggi. ${ }^{11}$ Steers mengungkapkan faktor-faktor yang memberikan pengaruh

${ }^{11}$ Stephen P. Robbins and Timothy A. Judge, Organizational Behavior (New Jersey: Pearson Prentice Hall, 2007), 501. 
Djamaluddin Perawironegoro: Hubungan antara Struktur Organisasi dengan Efektifitas Organisasi di Pesantren

pada efektifitas organisasi, yaitu ciri organisasi, dalam hal ini disebutkan struktur dan teknologi. $^{12}$

Robbins menyatakan bahwa apa yang membuat organisasi efektif adalah struktur organisasi yang tepat. ${ }^{13}$ Gibson et. al menyebutkan, di antara faktor-faktor yang mempengaruhi efektifitas organisasi adalah environment, technology, strategic choices, structure, processes, and culture. ${ }^{14}$ Daft menyebutkan bahwa structure is a powerful tool for reaching strategic goals, and a strategy's success often is determined by its fit with organizational structure. ${ }^{15}$ Etzioni dalam studinya yang berjudul Authority Structure and Organizational Effectiveness, menyebutkan bahwa otoritas dalam struktur organisasi memberikan pengaruh pada efektifitas organisasi. ${ }^{16}$

Kajian empiris pengaruh struktur organisasi terhadap efektifitas organisasi dilakukan oleh Gammahendra, et. al yang mendapatkan suatu kesimpulan bahwa struktur organisasi memberikan pengaruh terhadap efektifitas organisasi. ${ }^{17}$ Disertasi Susnadati pada tahun 2007 menjelaskan bahwa faktor-faktor yang memiliki pengaruh determinan terhadap efektifitas organisasi secara signifikan adalah; struktur organisasi, budaya organisasi, dan lingkungan organisasi. Sedangkan konflik organisasi tidak mempengaruhi efektifitas organisasi secara signifikan. ${ }^{18}$

Hasil penelitian yang dilakukan oleh Basol dan Dogerlioglu, menjelaskan kesimpulan bahwa beberapa variabel dalam struktur organisasi seperti formalisasi, sentralisasi dan spesialisasi mampu meningkatkan efektifitas organisasi. Sedangkan ukuran organisasi tidak menjadi faktor yang mempengaruhi tingkat efektifitas organisasi, bahkan pengaruhnya adalah negatif. ${ }^{19}$

Studi yang dilakukan oleh Razia, mengungkapkan bahwa terdapat hubungan yang signifikan antara struktur organisasi dengan efektifitas organisasi. Dalam kajiannya disebutkan bahwa empat konstruk dari struktur organisasi yaitu formalisasi,

\footnotetext{
${ }^{12}$ Richard M. Steers, Efektifitas Organisasi..., 209-214.

${ }^{13}$ Stephen P. Robbins, Teori Organisasi..., 53.

${ }^{14}$ James L. Gibson, et.al. Organizations: Behavior, Structure, Processes (New York: Mc GrawHill Irwin, 2009), 16.

${ }^{15}$ Richard L. Daft, Management (USA: South Western, 2010), 244.

${ }^{16}$ Amitai Etzioni, "Authority Structure and Organizational Effectiveness," Administrative Science Quarterly, Vol. 4, No. 1 (1959): 43.

${ }^{17}$ Fianda Gammahendra, Djamhur Hamid, dan Muhammad Faisal Riza, "Pengaruh Struktur Organisasi terhadap Efektiftas Organisasi Studi Pada Persepsi Pegawai Tetap Kantor Perwakilan Bank Indonesia Kediri," Jurnal Administrasi Bisnis, Vol.7, No. 2, (2014): 1.

${ }^{18}$ Susnadati, "Faktor-faktor Determinan..."

${ }^{19}$ Esra Basol and Ozgur Dogerlioglu, "Structural Determinant...," 13.
} 
integrasi horizontal, komunikasi, dan pengambilan keputusan merupakan hal yang penting bagi efektifitas organisasi. ${ }^{20}$

Disertasi Vinitwatanakhun menghasilkan suatu kesimpulan bahwa kepemimpinan, teknologi, strategi perencanaan, dan pengembangan sumber daya manusia memberikan penjelasan tentang efektifitas organisasi. Sedangkan faktor-faktor lain seperti lingkungan, budaya, desain struktur, dan kontrol kekuasaan tidak memberikan pengaruh terhadap efektifitas organisasi. ${ }^{21}$ Senada dengan hal tersebut, adalah Naserinajafabady et.al pada hasil penelitiannya menjelaskan tidak terdapat hubungan yang positif antara struktur organisasi dengan efektifitas organisasi. Dengan kata lain struktur organisasi tidak memberikan pengaruh terhadap efektifitas organisasi. $^{22}$

Hasil kajian teoritis menunjukkan hubungan yang positif antara struktur organisasi dengan efektifitas organisasi. Hasil kajian empiris terdapat dua temuan penelitian, yaitu struktur organisasi berpengaruh signifikan terhadap efektifitas organisasi, dan struktur organisasi tidak berpengaruh signifikan terhadap efektifitas organisasi.

Berdasarkan kajian teoritis dan empiris tersebut dirumuskan hipotesis penelitian. Hipotesis yang diajukan adalah struktur organisasi berpengaruh secara signifikan terhadap efektifitas organisasi di Pondok Modern Darussalam Gontor.

Konsep struktur organisasi di pesantren dibangun oleh dimensi-dimensi pembagian tugas, otoritas, spesialisasi, departementalisasi, orientasi impersonal, dan wewenang yang bersifat interaktif. Dimensi-dimensi yang menjadi ciri-ciri struktur organisasi di pesantren disampaikan Mastuhu, yang terdiri dari; a) memiliki dua sayap, sayap 1 menjaga kebenaran absolute, dan sayap -2 menjaga kebenaran relatif; b) supremasi sayap 1 atas sayap 2; c) sayap 1 dijaga oleh kiai utama dibantu oleh kiai-kiai dan ustadz yang dipilih dengan standar keilmuan sebagaimana kiai utama, sedangkan sayap 2 dijaga oleh kiai-kiai muda, ustadz dan santri; d) kiai utama merupakan pimpinan spiritual dan tokoh kunci pesantren, hubungan dengannya dilandasi kesadaran akan keberkahan, keikhlasan, dan ibadah; e) pembagian kerja antar unit cenderung kurang tajam dan banyak terdapat kesamaan; f) gaya kerja dalam struktur organisai

\footnotetext{
${ }^{20}$ Mbaraka Razia, "A Comparative Analysis of Organizational Structure and Effectiveness between Public and Private Universities; A Case of University of East Africa-Baraton and Moi University in Kenya," International Journal of Humanities and Social Science Invention, Vol. 4 (2015): 15-25.

${ }^{21}$ WatanaVinitwatanakhun, "Factors Affecting..." Culture..."

${ }^{22}$ Razieh Naserinajafabady, Hassan Rangriz, and Javad Mehrabi, "Effects of Organizational
} 
pesantren pada umumnya masih merupakan garis lurus ke atas, artinya setiap unit kerja bergantung pada atasan langsung. ${ }^{23}$

Berdasarkan hasil penelitian yang telah dilakukan, ditemukan bahwa struktur organisasi berjalan dengan sangat baik. Hasil analisis data dengan menggunakan analisis model struktural berbasis varian mendapatkan nilai korelasi antara struktur organiasi dengan efektifitas organisasi sebesar 0,553. Dibandingkan dalam tabel intreperetasi korelasi, menghasilkan kesimpulan bahwa hubungan yang demikian itu dalam kategori cukup atau sedang.

Hasil uji olah data bootstrapping menghasilkan angka t statistik 5,896. Dengan kriteria apabila nilai $\mathrm{T}$-statistik $\geq \mathrm{T}$-tabel yaitu 1.96 maka $\mathrm{H}_{0}$ ditolak. Hasil tersebut memberikan nilai t statistik lebih besar daripada t tabel $(5,896>1,96)$. Disimpulkan bahwa $\mathrm{H}_{0}$ ditolak, yaitu terdapat pengaruh yang signifikan struktur organisasi terhadap efektifitas organisasi di Pondok Modern Darussalam Gontor Ponorogo.

Hasil penelitian ini secara teoritis mendukung teori yang disampaikan oleh Steers, yang mengungkapkan bahwa struktur organisasi mempengaruhi keberhasilan suatu perusahaan dalam mencapai tujuannya. ${ }^{24}$ Robbins, mengungkapkan bahwa yang membuat organisasi efektif adalah struktur organisasi yang tepat. ${ }^{25}$ Robbins dan Judge, mengungkapkan bahwa dalam rangka mengurangi ambiguitas dari para pegawai, dan klarifikasi tentang pekerjaan, pelaporan, kerjasama dan koordinasi, struktur organisasi membentuk sikap, memfasilitasi, dan memotivasi mereka untuk kinerja yang tinggi ${ }^{26}$. Daft, mengungkapkan bahwa struktur organisasi merupakan alat yang kuat dalam mencapai ketercapaian tujuan strategis, dan ketercapai tujuan strategis tersebut ditentukan oleh kesesuaiannya dengan struktur organisasi. Gibson et.al, menyebutkan berbagai hal yang mempengaruhi efektifitas organisasi diantaranya adalah struktur organisasi $^{27}$. Para ahli tersebut mengungkapkan satu kesamaan teori akan berpengaruhnya struktur organisasi terhadap kinerja organisasi atau efektifitas organisasi.

Hasil penelitian ini juga mendukung kajian empiris yang menunjukkan keberpengaruhan struktur organisasi dengan efektifitas organisasi disampaikan oleh Etzioni, yang menyebutkan bahwa faktor penting dalam yang menunjukkan kemampuan

\footnotetext{
${ }^{23}$ Mastuhu, Dinamika ..., 74-78.

${ }^{24}$ Richard M. Steers, Efektifitas Organisasi..., 70.

${ }^{25}$ Stephen P. Robbins, Teori Organisasi..., 53.

${ }^{26}$ Stephen P. Robbins and Timothy A. Judge, Organizational Behavior..., 501.

${ }^{27}$ James L. Gibson et.al, Organizations..., 16.
} 
organisasi mencapai tujuannya adalah struktur otoritas. ${ }^{28}$ Gammahendra et.al, yang melakukan penelitian pengaruh struktur organisasi terhadap efektifitas organisasi mendapatkan kesimpulan bahwa struktur organisasi berpengaruh terhadap efektifitas organisasi. ${ }^{29}$ Susnadati pada penelitian yang dilakukan untuk guru-guru SMA di kota Semarang menjelaskan bahwa struktur organisasi memiliki pengaruh yang signifikan terhadap efektifitas organisasi. ${ }^{30}$ Basol dan Dogerlioglu yang menyatakan dimensidimensi dalam struktur organisasi seperti formalisasi, sentralisasi dan spesialisasi mampu meningkatkan efektifitas organisasi. ${ }^{31}$ Razia mengungkapkan hubungan yang signifikan antara struktur organisasi dengan efektifitas organisasi. Berdasarkan kajian yang telah dilakukan olehnya, yang menyebutkan bahwa empat konstruk dari struktur organisasi yaitu formalisasi, integrasi horizontal, komunikasi, dan pengambilan keputusan merupakan hal yang penting bagi efektifitas organisasi. ${ }^{32}$

Hasil penelitian ini yang menunjukkan pengaruh yang signifikan dari struktur organisasi terhadap efektifitas organisasi. Kajian empiris yang berlawanan dengan kesimpulan ini adalah Gavrea et.al, menguji 10 variabel yang dapat mempengaruhi efektifitas organisasi yaitu; strategi, kepemimpinan, struktur, kualitas, inovasi dan pengembangan, teknologi informasi, penilaian kinerja, pegawai, manajemen korporasi, dan lingkungan eksternal. Dari berbagai variabel tersebut, ditemukan signifikasi hubungan dengan kinerja organisasi, hanya variabel struktur yang tidak memiliki signifikansi hubungan dengannya. ${ }^{33}$ Vinitwatanakhun, dalam disertasinya mengungkapkan suatu temuan bahwa kepemimpinan, teknologi, strategi perencanaan, dan pengembangan sumber daya manusia memberikan penjelasan tentang efektifitas organisasi. Sedangkan faktor-faktor lain seperti lingkungan, budaya, desain struktur, dan kontrol kekuasaan tidak memberikan pengaruh terhadap efektifitas organisasi. ${ }^{34}$ Naserinjafabady et.al, dalam penelitiannya mengungkapkan bahwa tidak terdapat hubungan yang positif antara struktur organisasi dengan efektifitas organisasi. Dengan

\footnotetext{
${ }^{28}$ Amitai Etzioni, "Authority Structure..."

${ }^{29}$ Fianda Gammahendra, Djamhur Hamid, dan Muhammad Faisal Riza, "Pengaruh Struktur Organisasi..."

${ }^{30}$ Susnadati, "Faktor-faktor Determinan..."

${ }^{31}$ Esra Basol and Ozgur Dogerlioglu, "Structural Determinant..." 1-13.

${ }^{32}$ Mbaraka Razia, "A Comparative Analysis..."

${ }^{33}$ Corina Gavrea, et. all, "Determinants of Organizational Performance; The Case of Romania," Management and Marketing, Vol. 6, No. 2 (2011): 298.

${ }^{34}$ WatanaVinitwatanakhun, "Factors Affecting..."
} 
kata lain struktur organisasi tidak memberikan pengaruh yang signifikan terhadap efektifitas organisasi. ${ }^{35}$

Dengan demikian dapat disimpulkan bahwa struktur organisasi di pondok modern Ponorogo berpengaruh secara signifikan terhadap efektifitas organisasi. Pengaruh tersebut tergolong rendah yaitu 30, $5 \%$, demikian itu memiliki makna bahwa struktur organisasi telah berjalan di pesantren, akan tetapi kurang optimal. Karena optimalisasi dari dimensi-dimensi struktur organisasi dari para guru dan dan santri sebagai pengurus akan berdampak pada signifikansi pengaruh terhadap efektifitas organisasi di pesantren. Ada beberapa alasan yang menyebabkan hal ini terjadi, yaitu;

1. Struktur organisasi adalah bukan satu-satunya faktor yang dapat mempengaruhi efektifitas organisasi, sebagaimana diungkapkan oleh Steers, yang mengungkapkan bahwa dalam kategori ciri organisasi selain struktur organisasi terdapat teknologi yang turut mempengaruhi efektifitas organisasi. ${ }^{36}$

2. Gibson et.al menyebutkan struktur organisasi tidak berperan secara mandiri terhadap efektifitas organisasi. Terdapat faktor lain yaitu lingkungan, teknologi, pilihan strategis, proses, dan budaya yang turut mempengaruhi efektifitas organisasi. $^{37}$

3. Proposisi yang disampaikan oleh Mastuhu, ${ }^{38}$ masih terbatas pada dimensi spesialisasi kerja, departementalisasi, orientasi impersonal, desentralisasi dan otoritas. Sedangkan dimensi lain seperti formalisasi dan rentang kendali belum menjadi kajian yang difokuskan dalam pola struktur organisasi di pesantren. Robbins, ${ }^{39}$ Robbins dan Judge, ${ }^{40}$ Robbins dan Coulter, ${ }^{41}$ Daft, $^{42}$ dan Hanggraeni ${ }^{43}$ menyebutkan akan peran penting formalisasi dan rentang kendali dalam struktur organisasi. Formalisasi di sini dimaksudkan tingkat di mana pekerjaan di sebuah organisasi distandarkan. Rentang kendali dimaksudkan jumlah bawahan dari seorang manajer yang dapat diarahkan secara efektif dan efisien.

\footnotetext{
${ }^{35}$ Razieh Naserinajafabady, Hassan Rangriz, and Javad Mehrabi, "Effects of Organizational Culture..." 355-361.

${ }^{36}$ Richard M. Steers, Efektifitas Organisasi..., 209-214.

${ }^{37}$ James L. Gibson, et.al, Organizations..., 378.

${ }^{38}$ Mastuhu, Dinamika..., 76-78.

${ }^{39}$ Stephen P. Robbins, Teori Organisasi..., 91-118.

${ }^{40}$ Stephen P. Robbins and Timothy A. Judge, Organizational Behavior..., 478.

${ }^{41}$ Stephen P. Robbins and Mary Coulter, Management..., 265-273.

${ }^{42}$ Richard L. Daft, Management..., 244.

${ }^{43}$ Dewi Hanggraeni, Perilaku Organisasi - Teori, Kasus, dan Analisis (Jakarta: Lembaga Penerbit Fakultas Ekonomi UI, 2011), 134-140.
} 
4. Robbins dan Judge mengungkapkan bahwa formalisasi dapat diminimalisir dengan budaya organisasi yang kuat. ${ }^{44}$ Dengan kata lain, ketika budaya organisasi di pesantren kuat, akan meningkatkan prilaku konsisten dari warga pesantren, demikian itu meminimalisir formalisasi.

Dengan demikian ditemukan bahwa struktur organisasi di Pondok Modern Gontor Ponorogo yang terdiri dari dimensi-dimensi; a) pembagian struktur organisasi berdasarkan jenis nilai yang mendasarinya. Terdapat nilai-nilai agama dengan kebenaran absolut yang dijaga oleh para kiai senior dan terdapat pula yang betanggungjawab untuk akan pengamalan nilai-nilai tersebut. Untuk kelompok pertama disebut sayap 1, sedangkan untuk yang kedua disebut sebaga sayap 2; b) supremasi sayap 1 atas sayap 2 (otoritas), pada kondisi ini sayap 2 tidak diperkenankan untuk bertentangan dengan sayap 1; c) sayap 1 dijaga oleh kiai utama dibantu oleh kiai-kiai dan para asatidz yang dipilih dengan standar keilmuan sebagaimana kiai utama, sedangkan sayap 2 dijaga oleh kiai-kiai muda, ustadz dan santri (spesialisasi); d) kiai utama merupakan pimpinan spiritual dan tokoh kunci pesantren, hubungan dengannya dilandasi kesadaran akan keberkahan, keikhlasan, dan ibadah (orientasi impersonal); e) pembagian kerja cenderung kurang tajam dengan adanya kesamaan-kesamaan antar unit, akan tetapi yang demikian itu memiliki kekhususan masing-masing. Dalam mengelola unit-unit tersebut inisiatif bergantung pada pengelola unit, yang kemudian diajukan kepada pengasuh atau kiai untuk diminta restu dan izinnya. Pada pelaksanaannya inisiatif yang diberikan izin adalah dengan batasan tidak bertentangan dengan ajaran agama dan tradisi pesantren, juga memiliki tujuan untuk kemajuan santri dan pesantren (departementalisasi); f) gaya kerja dalam struktur organisai pesantren pada umumnya masih merupakan garis lurus ke atas, sehingga atasan dari unit bertanggung jawab secara langsung. Akan tetapi sekalipun demikian, keberhasilan kerja dalam struktur organisasi di pesantren merupakan penjumlahan dari hasil kerja masingmasing unit. Sehingga sekalipun terfokus ke atas, tetapi hubungan kerja sama antar unit merupakan kelaziman. Model yang demikian itu adalah model wewenang yang bersifat interaktif antar unit dan bagian-bagian di pesantren; g) rasio jumlah pengurus sebagai pimpinan dan anggota. (rentang kendali); dan h) tingkat sejauh mana suatu pekerjaan distandarisasikan (formalisasi).

${ }^{44}$ Stephen P. Robbins and Timothy A. Judge, Organizational Behavior..., 514-515. 
Optimalisasi dari kinerja struktur organisasi diharapkan mampu untuk membantu meningkatkan kinerja organisasi di Pondok Modern Gontor Ponorogo. Pada saat dimensi-dimensi struktur organisasi berjalan dengan sangat baik, maka akan turut mempengaruhi efektifitas organisasi pesantren. Sebaliknya, jika struktur organisasi tidak tertata dengan baik harapan untuk ketercapaian efektifitas organisasi berada pada bangunan budaya yang kuat.

\section{Simpulan dan Saran}

\section{Simpulan}

Pesantren sebagai sebuah institusi pendidikan yang memiliki visi, misi, dan tujuan yang jelas diharapkan untuk mampu bertahan dan berkembang dalam menghadapi dinamika globalisasi, perkembangan teknologi dan informasi, demokratisasi, dan pengembangan ilmu pengetahuan. Beberapa dekade terakhir, perkembangan pesantren berlangsung dengan sangat massif yaitu dengan menyelenggarakan berbagai bentuk pendidikan formal. Tentu perkembangan ini berimplikasi pada pengembangan struktur organisasi yang dibangun.

Berdasarkan penelitian ini, hubungan antara struktur organisasi dengan efektifitas organisasi masih tergolong cukup yaitu dengan nilai 0,553. Sedangkan nilai koefisien determinasi menunjukkan nilai 0,305 (30,5\%), demikian itu menunjukkan pengaruh lebih besar diberikan faktor lain di luar struktur organisasi. Faktor lain tersebut adalah budaya organisasi, teknologi informasi, manajemen sumber daya manusia, dan lain-lain.

\section{Saran}

Kepada para pengelola pesantren diharapkan untuk mampu menghidupkan struktur organisasi yang telah dibuat dengan memperhatikan pembagian kerja, spesialisasi pelaksana, formalisasi, orientasi impersonal, otoritas, dan wewenang yang interaktif. Demikian juga terhadap sasaran dari efektifitas organisasi pesantren agar dapat dicapai yang terdiri dari kepemilikian nilai dan falsafah, orientasi pendidikan, pendidikan berbasis asrama, santri mengelola sendiri aktifitas dan kegiatannya, pendidikan diorientasikan untuk masyarakat, dan kepemimpinan kyai yang profesional.

Kepada peneliti selanjutnya untuk dapat melakukan penelitian pada pendalaman atau pengembangan aspek-aspek dari struktur organisasi, efektifitas organisasi, atau faktor lain yang mempengaruhi efektifitas organisasi di pesantren. Sehingga dengan memiliki ragam varian prediktor terhadap efektifitas organisasi di pesantren, dapat mengembangkan pesantren lebih produktif dan sistematis. 


\section{E. Daftar Pustaka}

Amah, Edwinah; Mildre Daminabo-Weje; dan Roberta Dosunmu. "Size and Organizational Effectiveness: Maintaining a Balance." Advances in Management \& Applied Economics, Vol. 3, No. 5 (2013).

Basol, Esra and Ozgur Dogerlioglu. "Structural Determinant of Organizational Effectiveness.” Journal of Organizational Management Studies, (2014).

Daft, Richard L. Management. USA: South Western, 2010.

Etzioni, Amitai. “Authority Structure and Organizational Effectiveness.” Administrative Science Quarterly, Vol. 4, No. 1, (1959).

Gammahendra, Fianda; Djamhur Hamid; dan Muhammad Faisal Riza. "Pengaruh Struktur Organisasi terhadap Efektiftas Organisasi Studi pada Persepsi Pegawai Tetap Kantor Perwakilan Bank Indonesia Kediri." Jurnal Administrasi Bisnis, Vol. 7, No. 2, (2014).

Gavrea, Corina. et. al. "Determinants of Organizational Performance; The Case of Romania." Management and Marketing, Vol. 6, No. 2 (2011).

Gibson, James L. et.al. Organizations: Behavior, Structure, Processes. New York: Mc Graw-Hill Irwin, 2009.

Hanggraeni, Dewi. Perilaku Organisasi - Teori, Kasus, dan Analisis. Jakarta: Lembaga Penerbit Fakultas Ekonomi UI, 2011.

Madjid, Nurcholish. Bilik-Bilik Pesantren: Sebuah Potret Perjalanan. Jakarta: Paramadina, 1997.

Mastuhu. Dinamika Sistem Pendidikan Pesantren. Jakarta: INIS, 1994.

Naserinajafabady, Razieh; Hassan Rangriz; and Javad Mehrabi. "Effects of Organizational Culture, Structure, and Strategy on Organizational Effectiveness by Using Knowledge Management Case Study; Seven International Transportation Company." International Research Journal of Applied and Basic Science, Vol. 7, No. 6, (2013).

Razia, Mbaraka. "A Comparative Analysis of Organizational Structure and Effectiveness between Public and Private Universities; A Case of University of East Africa-Baraton and Moi University in Kenya." International Journal of Humanities and Social Science Invention, Vol. 4 (2015).

Robbins, Stephen P. Teori Organisasi: Struktur, Desain, dan Aplikasi. Alih bahasa Jusuf Udaya. Jakarta: Penerbit Arcan, 1994.

Robbins, Stephen P. \& Mary Coulter. Manajemen. Alih bahasa T. Hermaya. Jakarta: Indeks, 2005.

Robbins, Stephen P. and Timothy A. Judge. Organizational Behavior. New Jersey: Pearson Prentice Hall, 2007. 
Djamaluddin Perawironegoro: Hubungan antara Struktur Organisasi dengan Efektifitas Organisasi

Steers, Richard M., Efektifitas Organisasi. Alih bahasa Magdalena Jamin. Jakarta: Lembaga PPM dan Penerbit Erlangga, 1985.

Susnadati. "Faktor-faktor Determinan Keefektifan Organisasi SMA Negeri di Semarang Pada Era Desentralisasi Pendidikan." Disertasi. Program Studi Manajemen Pendidikan, Program Pascasarjana Universitas Negeri Semarang, 2007.

Usman, Husaini. Manajemen: Teori, Praktik dan Riset Pendidikan. Edisi 3. Jakarta: Bumi Aksara, 2011.

Vinitwatanakhun, Watana. "Factors Affecting Organizational Effectiveness of Nursing Institutes in Thailand." Dissertation. National Institute of Development Administration Bangkok Thailand 1998.

Wahid, Shalahuddin. Transformasi Pesantren Tebuireng; Menjaga Tradisi di Tengah Tantangan. Malang; UIN-Maliki Press, 2011.

Wiyono, Gendro. Merancang Penelitian Bisnis Dengan Alat Analisis SPSS 17.0 \& SmartPLS 2.0. Edisi 1. Yogyakarta: UPP STIM YKPN, 2011.

Zarkasyi, Abdullah Syukri. "Pengembangan Pendidikan Pesantren di Era Otonomi Pendidikan; Pengalaman Pondok Modern Darussalam Gontor." Pidato Penerimaan Doktor Honoris Causa dalam Bidang Pendidikan Islam di UIN Syarif Hidayatullah Jakarta, Jakarta, 2005.

Zarkasyi, Abdullah Syukri. Gontor \& Pembaharuan Pendidikan Pesantren. Jakarta: Raja Grafindo Persada, 2005.

Zarkasyi, Abdullah Syukri. Manajemen Pesantren: Pengalaman Pondok Modern Gontor. Ponorogo: Trimurti Press, 2005. 